\title{
Analisis kesalahan siswa dalam menyelesaikan soal cerita program linear berdasarkan Newman's error analysis
}

\author{
Suratih $^{1 *}$, Heni Pujiastuti ${ }^{1}$ iD \\ 1 Jurusan Pendidikan Matematika, Universitas Sultan Ageng Tirtayasa, Serang, Indonesia \\ * Corresponding Author. E-mail: suratih237@gmail.com
}

\begin{tabular}{|c|c|}
\hline ARTICLE INFO & ABSTRACT \\
\hline $\begin{array}{l}\text { Article History: } \\
\text { Received: } 31 \text { March } 2020 \\
\text { Revised: } 23 \text { Sept. } 2020 \\
\text { Accepted: } 18 \text { Dec. } 2020 \\
\text { Keywords: } \\
\text { Analisis kesalahan siswa, } \\
\text { Soal cerita program linear, } \\
\text { Students' error analysis, } \\
\text { Newman's error analysis, } \\
\text { Word problems of linear } \\
\text { program. }\end{array}$ & $\begin{array}{l}\text { Tujuan penelitian ini adalah untuk mendeskripsikan kesalahan siswa dalam menyelesaikan soal } \\
\text { cerita program linear. Subjek dari penelitian ini yaitu siswa kelas XI SMAN } 5 \text { Kota Serang }(n=30) \text {. } \\
\text { Pengumpulan data menggunakan tes tertulis dan dokumentasi. Analisis data menggunakan } \\
\text { analisis deskriptif kualitatif. Dalam analisis ini, kesalahan siswa dikategorikan berdasarkan } \\
\text { Newman's Error Analysis. Hasil penelitian menunjukkan bahwa masih banyak siswa yang mela- } \\
\text { kukan kesalahan dalam menyelesaikan soal cerita program linear. Kesalahan yang paling banyak } \\
\text { terjadi adalah kesalahan penulisan jawaban akhir, sedangkan kesalahan yang paling sedikit } \\
\text { terjadi adalah kesalahan transformasi. Kesalahan membaca terjadi karena siswa tidak mampu } \\
\text { memaknai kalimat dengan tepat dan tidak mampu menemukan kata kunci atau informasi } \\
\text { dalam soal. Kesalahan memahami soal terjadi karena siswa keliru dalam menuliskan apa yang } \\
\text { diketahui dan ditanyakan dalam soal. Kesalahan transformasi terjadi karena siswa tidak mampu } \\
\text { mentransformasikan masalah ke dalam model matematika dan tidak teliti dalam melakukan } \\
\text { operasi matematika. Kesalahan keterampilan proses terjadi karena siswa mengalami kesalahan } \\
\text { prosedur seperti salah dalam menulis fungsi tujuan yang akan dicapai dan tidak dapat mem- } \\
\text { proses lebih lanjut solusi dari penyelesaian soal. Kesalahan penulisan jawaban terjadi karena } \\
\text { banyak siswa yang tidak menuliskan kesimpulan, menuliskan kesimpulan tetapi tidak tepat, } \\
\text { serta menuliskan kesimpulan yang salah. }\end{array}$ \\
\hline
\end{tabular}

Scan me:

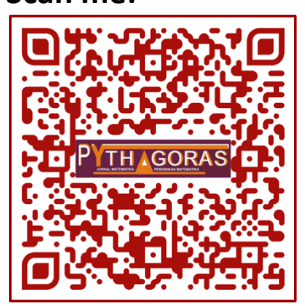

This study aimed to describe students' errors in solving word problems of the linear program. This study's subjects were eleventh-grade students of SMAN 5 (Senior High School) in Serang City ( $n=$ 30), Indonesia. Data collection using the written test and documentation. Data analysis using qualitative descriptive analysis. In this analysis, students' errors were categorized based on Newman's Error Analysis. The results showed that many students made errors in solving word problems of the linear program. The most common error was writing the final answer, while the error that occurs the least was the transformation error. Reading errors occur because students could not interpret sentences correctly and could not found keywords or information in the problems. Errors in understanding the problems occur because students made errors in writing what they know and were asked in the problems. Transformation errors occur because students could not transform problems into mathematical models and were not careful in performing mathematical operations. Process skill errors occur because students experienced procedural errors such as incorrectly writing the objective function to be achieved and could not do the next process to find a solution to the problems. Errors in writing answers occur because many students did not write conclusions, write inaccurate conclusions, and write wrong conclusions.

This is an open access article under the CC-BY-SA license

\section{How to Cite:}

Suratih, S., \& Pujiastuti, H. (2020). Analisis kesalahan siswa dalam menyelesaikan soal cerita program linear berdasarkan Newman's error analysis. Pythagoras: Jurnal Pendidikan Matematika, 15(2), 111-123. https://doi.org/10.21831/pg.v15i2.30990

https://doi.org/10.21831/pg.v15i2.30990

\section{PENDAHULUAN}

Matematika merupakan salah satu disiplin ilmu yang mendasari perkembangan teknologi modern. Oleh karena itu, matematika perlu diberikan kepada semua siswa untuk membekali siswa dengan kemampuan berpikir 
logis, analitis, sistematis, kritis dan kreatif, serta kemampuan bekerja sama (Jamal, 2018). Hal ini sesuai dengan pendapat Soedjadi (2000) bahwa salah satu tujuan umum matematika yaitu mempersiapkan siswa agar dapat menggunakan pola pikir matematika dalam kehidupan sehari-hari. Salah satu bentuk soal yang dapat digunakan untuk mengukur kemampuan siswa dalam pembelajaran matematika yaitu bentuk soal cerita (Rahardjo \& Waluyati, 2011).

Soal cerita matematika merupakan salah satu soal yang dapat digunakan untuk mengetahui keterampilan pemecahan masalah, karena sebagian besar soal cerita menghendaki siswa untuk menghubungkan situasi dunia nyata dengan konsep matematika (Seifi et al., 2012). Situasi dunia nyata yang disajikan dalam soal cerita matematika biasanya berupa teks tanpa memuat notasi matematika itu sendiri (Boonen et al., 2016). Dalam memecahkan soal cerita matematika, siswa harus mampu memahami isi soal cerita, mengetahui obyek-obyek matematika yang harus diselesaikan, mampu memisalkannya ke dalam model matematika, kemudian mampu memilih operasi hitung yang tepat untuk menyelesaikan soal cerita tersebut, hingga tahap akhir yaitu penyelesaian serta penarikan kesimpulan (Satoto et al., 2013). Oleh karena itu, penggunaan soal cerita dalam kegiatan belajar matematika dapat meningkatkan keterampilan siswa dalam menghubungkan antara materi matematika yang sudah dipelajari dengan situasi di kehidupan nyata (Angateeah, 2017)

Salah satu aspek atau ruang lingkup materi matematika pada satuan pendidikan Sekolah Menengah Atas (SMA) yang dirasa sulit oleh siswa adalah aljabar. Pokok bahasan aljabar yang dipelajari di sekolah banyak digunakan untuk memecahkan masalah dalam kehidupan sehari-hari (Haryarti et al., 2016). Salah satu topik yang terdapat dalam pokok bahasan aljabar adalah program linear. Materi program linear merupakan materi yang dipelajari di semester ganjil kelas XI. Dalam materi program linear masalah-masalah yang disajikan berbentuk soal cerita. Soal cerita biasanya diwujudkan dalam kalimat yang di dalamnya terdapat persoalan atau permasalahan yang penyelesaiannya menggunakan keterampilan berhitung (Budiyono, 2008).

Kesulitan siswa dalam memecahkan masalah pada soal cerita program linear dibuktikan dengan rendahnya daya serap siswa SMA Negeri 5 Kota Serang pada Ujian Nasional tahun pelajaran 2017/2018 dalam menyelesaikan masalah yang berkaitan dengan program linear yaitu sebesar 29,16\% (Puspendik, n. d.). Hal tersebut mengindikasikan adanya kendala yang dialami oleh siswa dalam mengerjakan soal-soal program linear. Kesulitan dalam menyelesaikan soal cerita dapat menyebabkan terjadinya kesalahan dalam menyelesaikan soal tersebut (Fitriatien, 2019). Adanya kesulitan tersebut juga dapat berpengaruh terhadap hasil belajar siswa yang menjadi rendah.

Berdasarkan permasalahan yang telah dikemukakan, perlu adanya suatu upaya untuk mengatasi kesulitan siswa dalam menyelesaikan soal cerita. Kesulitan siswa dalam menyelesaikan masalah matematika dapat diatasi dengan memetakan terlebih dahulu kesalahan yang dilakukan siswa dalam menyelesaikan masalah matematika (Hadi et al., 2018; Pradini, 2019; Rafi \& Retnawati, 2018). Dengan mengetahui kesalahan siswa tersebut, guru dapat mengetahui kesulitan yang dialami siswa dan dapat menentukan langkah pembelajaran yang efektif, sehingga diharapkan mengurangi terjadinya kesalahan. Menurut Satoto (2012) salah satu cara yang dapat digunakan untuk mengidentifikasi kesalahan siswa adalah dengan melakukan kajian analisis kesalahan. Hal ini sejalan dengan pendapat Nurussafa'at et al. (2016), bahwa untuk mengetahui kesalahan yang dilakukan siswa perlu adanya analisis lebih lanjut untuk mendapatkan gambaran yang jelas dan rinci atas kelemahan-kelemahan siswa dalam menyelesaikan soal cerita.

Salah satu analisis kesalahan yang bisa dilakukan adalah menggunakan prosedur Newman's Error Analysis. Prosedur Newman diperkenalkan pertama kali pada tahun 1977 oleh Anne Newman, seorang guru mata pelajaran matematika di Australia. Prosedur Newman merupakan tahapan untuk memahami dan menganalisis bagaimana siswa menjawab sebuah permasalahan yang ada pada soal (Rahmawati \& Permata, 2018). Prosedur Newman dikembangkan untuk membantu guru ketika berhadapan dengan siswa yang mengalami kesulitan dengan masalah soal cerita matematis (Newman, 1983).

Penelitian yang berkaitan dengan analisis kesalahan siswa sudah banyak dilakukan oleh para peneliti pada topik matematika tertentu, seperti mendeskripsikan kesalahan siswa dalam menyelesaikan soal materi sistem persamaan linier dua variabel (Sangadah, 2016), pertidaksamaan kuadrat (Jamal, 2018), volume prisma (Nurussafa'at et al., 2016), dan bangun ruang sisi datar (Darmawan et al., 2018). Penelitian-penelitian tersebut menggunakan prosedur Newman dalam menganalisis kesalahan siswa. Newman menyarankan lima tahapan pengerjaan dalam menyelesaikan soal dan dapat membantu menemukan penyebab terjadi kesalahan siswa ketika menyelesaikan soal uraian yaitu membaca, memahami makna suatu permasalahan, transformasi, keterampilan proses, dan penulisan jawaban (Singh et al., 2010). Berdasarkan tahapan tersebut, maka untuk memahami serta menganalisis 
bagaimana siswa melakukan kesalahan dapat diidentifikasi dari kesalahan dalam membaca (reading error), kesalahan memahami masalah (comprehension error), kesalahan dalam melakukan transformasi (transformation error), kesalahan dalam melakukan keterampilan proses (process skill error); dan kesalahan dalam menuliskan jawaban akhir (encoding error). Indikator-indikator untuk masing-masing jenis kesalahan yang digunakan dalam penelitian ini disajikan pada Tabel 1.

Berdasarkan latar belakang masalah dan kajian teori yang telah dikemukakan sebelumnya, dapat dipahami bahwa identifikasi kesalahan yang dilakukan siswa dalam menyelesaikan soal cerita penting dilakukan guna memperoleh informasi terkait kesulitan-kesulitan yang dialami siswa dalam menyelesaikan soal cerita tersebut. Informasi tersebut dapat dijadikan bahan refleksi bagi guru untuk perbaikan proses pembelajaran pada topik yang dianggap sulit oleh siswa. Dengan demikian, penelitian ini bertujuan untuk mendeskripsikan kesalahan siswa di SMA Negeri 5 Kota Serang dalam menyelesaikan soal cerita pada materi program linear berdasarkan prosedur Newman's error analysis. Pemilihan materi program linear dikarenakan materi tersebut merupakan salah satu materi yang dianggap sulit oleh siswa dan terdapat banyak konsep program linear yang dapat digunakan dalam kehidupan sehari-hari.

\section{METODE}

Penelitian ini termasuk penelitian deskriptif kualitatif. Penelitian ini dilaksanakan untuk menganalisis dan mendeskripsikan jenis kesalahan siswa kelas XI dalam menyelesaikan soal cerita program linear dengan mengacu pada prosedur Newman. Penelitian ini dilakukan di SMA Negeri 5 Kota Serang, Banten. Subjek dari penelitian ini terdiri dari 30 siswa kelas XI yang sudah selesai mempelajari materi tentang program linear. Siswa terdiri dari 19 perempuan dan 11 laki-laki yang memiliki kemampuan akademik yang heterogen (rendah, sedang, dan tinggi).

Instrumen utama dalam penelitian ini adalah peneliti sendiri dan instrumen pendukung berupa tes dan dokumentasi. Tes yang digunakan pada penelitian ini terdiri dari tiga soal cerita pada materi program linear yang dikaitkan dengan masalah kehidupan sehari-hari. Soal tes yang digunakan dalam penelitian ini diambil dari penelitian Larasati (2018). Data yang dikumpulkan dalam penelitian ini berupa jawaban siswa. Jawaban siswa tersebut akan digunakan untuk mengidentifikasi dan menentukan jenis kesalahan yang dilakukan siswa dalam menyelesaikan soal cerita pada materi program linear.

Setelah peneliti mendapatkan data hasil tes siswa, peneliti melakukan analisis data dengan menggunakan analisis deskriptif kualitatif. Dalam analisis data ini, kesalahan siswa dalam menyelesaikan soal cerita dikategorikan berdasarkan jenis kesalahan yang dikemukakan oleh Newman. Kesalahan siswa dianalisis menurut lima aspek kesalahan dalam prosedur Newman yang dijabarkan dalam beberapa indikator. Indikator jenis kesalahan yang dimaksud disajikan pada Tabel 1.

Tabel 1. Jenis kesalahan dan indikator berdasarkan prosedur Newman's error analysis

\begin{tabular}{|c|c|c|}
\hline Jenis Kesalahan & Indikator & Kode \\
\hline $\begin{array}{l}\text { Kesalahan membaca } \\
\text { (reading error) }\end{array}$ & $\begin{array}{l}\text { a. Siswa tidak dapat memaknai simbol-simbol dengan benar } \\
\text { b. Siswa tidak mampu menemukan makna kata, dari kalimat, atau istilah } \\
\text { yang sulit dalam soal cerita }\end{array}$ & $A$ \\
\hline $\begin{array}{l}\text { Kesalahan memahami } \\
\text { soal (comprehension } \\
\text { error) }\end{array}$ & $\begin{array}{l}\text { a. Siswa tidak menuliskan apa yang diketahui } \\
\text { b. Siswa menuliskan apa yang diketahui namun tidak tepat } \\
\text { c. Siswa tidak menuliskan apa yang ditanyakan } \\
\text { d. Siswa menuliskan apa yang ditanyakan namun tidak tepat }\end{array}$ & B \\
\hline $\begin{array}{l}\text { Kesalahan transformasi } \\
\text { (transformation error) }\end{array}$ & $\begin{array}{l}\text { a. Siswa salah dalam memilih operasi yang digunakan untuk menyele- } \\
\text { saikan soal }\end{array}$ & C \\
\hline $\begin{array}{l}\text { Kesalahan keterampilan } \\
\text { proses (process skills error) }\end{array}$ & $\begin{array}{l}\text { a. Siswa salah menggunakan kaidah atau aturan matematika yang benar } \\
\text { b. Siswa tidak dapat memproses lebih lanjut solusi dari penyelesaian soal } \\
\text { c. Kesalahan dalam melakukan perhitungan }\end{array}$ & D \\
\hline $\begin{array}{l}\text { Kesalahan penulisan } \\
\text { jawaban akhir (encoding } \\
\text { error) }\end{array}$ & $\begin{array}{l}\text { a. Siswa salah dalam menuliskan satuan dari jawaban akhir } \\
\text { b. Siswa tidak menuliskan kesimpulan } \\
\text { c. Siswa menuliskan kesimpulan tetapi tidak tepat }\end{array}$ & $E$ \\
\hline
\end{tabular}


Selanjutnya peneliti menentukan dan mendeskripsikan kesalahan siswa dalam menyelesaikan soal cerita sesuai dengan jenis kesalahan yang dijabarkan dalam indikator-indikator pada Tabel 1 . Indikator-indikator tersebut sejalan dengan pendapat White (2010) yang menyebutkan bahwa jenis-jenis kesalahan menurut prosedur Newman yang mungkin dilakukan siswa dalam menyelesaikan soal matematika, meliputi kesalahan karena ketidakcermatan, kesalahan membaca soal, kesalahan dalam memahami soal, kesalahan mentransformasikan, kesalahan dalam keterampilan proses, kesalahan dalam penulisan. Setiap kesalahan siswa pada lembar jawaban diberi kode kesalahan seperti pada Tabel 1, sesuai dengan jenis kesalahan yang dilakukannya. Adapun jika siswa tidak mengalami kesulitan, maka peneliti memberikan kode $F$, sedangkan jika siswa tidak menjawab soal, maka diberi kode $\mathrm{G}$.

\section{HASIL PENELITIAN}

\section{Gambaran Umum Kesalahan yang Dilakukan Siswa}

Berdasarkan prosedur Newman jenis kesalahan siswa dalam menyelesaikan soal dikategorikan menjadi lima kategori yaitu: (1) kesalahan membaca (Kode A), (2) kesalahan memahami soal (Kode B), (3) kesalahan transformasi (Kode C), (4) kesalahan keterampilan proses (Kode D), dan (5) kesalahan penulisan jawaban akhir (Kode E). Adapun kode $\mathrm{F}$ menunjukkan bahwa siswa mampu menjawab soal dengan benar dan kode $\mathrm{G}$ diberikan ketika siswa tidak menjawab soal. Gambaran umum kesalahan yang dilakukan siswa dalam menyelesaikan soal cerita pada materi program linear disajikan pada Tabel 2.

Tabel 2. Gambaran umum jenis kesalahan yang dilakukan siswa

\begin{tabular}{|c|c|c|c|c|c|c|c|}
\hline \multirow{2}{*}{$\begin{array}{l}\text { No. } \\
\text { siswa }\end{array}$} & \multicolumn{3}{|c|}{ Jenis kesalahan } & \multirow{2}{*}{$\begin{array}{l}\text { No. } \\
\text { siswa }\end{array}$} & \multicolumn{3}{|c|}{ Jenis kesalahan } \\
\hline & Soal 1 & Soal 2 & Soal 3 & & Soal 1 & Soal 2 & Soal 3 \\
\hline 1. & $\mathrm{~F}$ & $\mathrm{E}$ & G & 16. & $E$ & $\mathrm{C}, \mathrm{E}$ & G \\
\hline 2. & A & D & $D, E$ & 17. & $B, E$ & $B, E$ & D \\
\hline 3. & $A, D, E$ & G & $\mathrm{F}$ & 18. & $\mathrm{~F}$ & $\mathrm{~F}$ & G \\
\hline 4. & $A, D$ & $A, B, E$ & $E$ & 19. & $\mathrm{~F}$ & $\mathrm{D}, \mathrm{E}$ & D \\
\hline 5. & $\mathrm{~F}$ & G & G & 20. & $\mathrm{E}$ & $A, B, E$ & $\mathrm{E}$ \\
\hline 6. & $\mathrm{~F}$ & $\mathrm{E}$ & $\mathrm{G}$ & 21. & $\mathrm{E}$ & $\mathrm{D}$ & G \\
\hline 7. & $B, E$ & $A, B, C, E$ & $A, B, E$ & 22. & $B, E$ & $B, D$ & $B, E$ \\
\hline 8. & B & $\mathrm{B}, \mathrm{D}$ & B & 23. & $B, E$ & $\mathrm{~B}, \mathrm{E}$ & $A, B, E$ \\
\hline 9. & $\mathrm{~F}$ & $\mathrm{~F}$ & G & 24. & $\mathrm{E}$ & $A, B, C, D$ & G \\
\hline 10. & $B, E$ & G & G & 25. & $\mathrm{~F}$ & D & $A, C$ \\
\hline 11. & $\mathrm{~F}$ & $A, E$ & $\mathrm{E}$ & 26. & $A, E$ & D & D \\
\hline 12. & $E$ & $\mathrm{D}$ & $\mathrm{G}$ & 27. & $A, B, E$ & $\mathrm{~B}, \mathrm{E}$ & $A, B, C$ \\
\hline 13. & $B, E$ & $B, D$ & $B, D$ & 28. & $\mathrm{~F}$ & $E$ & D \\
\hline 14. & $A, B, E$ & G & G & 29. & $E$ & D & G \\
\hline 15. & $\mathrm{E}$ & $\mathrm{E}$ & $\mathrm{E}$ & 30. & B & $A, B, D$ & D \\
\hline
\end{tabular}

Tabel 2 menunjukkan bahwa kesalahan yang dilakukan siswa dalam menyelesaikan soal cerita pada materi program linear berbeda-beda. Berdasarkan Tabel 2 tersebut, dapat dikatakan bahwa masih banyak siswa yang melakukan kesalahan berdasarkan prosedur Newman. Adapun rekapitulasi kesalahan siswa dalam menyelesaikan soal cerita pada materi program linear disajikan pada Tabel 3.

Tabel 3. Rekapitulasi jenis kesalahan yang dilakukan siswa

\begin{tabular}{lrrrrrrrr}
\hline \multirow{2}{*}{ Jenis Kesalahan } & \multicolumn{3}{c}{ Soal 1 } & \multicolumn{2}{c}{ Soal 2 } & \multicolumn{2}{c}{ Soal 3 } & Rata-rata \\
\cline { 2 - 7 } & $n$ & $\%$ & $n$ & $\%$ & $n$ & $\%$ & persentase \\
\hline Membaca & 6 & 20 & 6 & 20 & 4 & 13,33 & 17,78 \\
Memahami soal & 10 & 33,33 & 11 & 36,67 & 6 & 20 & 30 \\
Transformasi & 0 & 0 & 3 & 10 & 2 & 6,67 & 5,56 \\
Ketrampilan proses & 2 & 6,67 & 12 & 40 & 7 & 23,33 & 23,33 \\
Penulisan jawaban akhir & 17 & 56,67 & 13 & 43,33 & 8 & 26,67 & 42,22 \\
\hline
\end{tabular}


Tabel 3 menunjukkan bahwa kesalahan yang paling banyak dilakukan oleh siswa adalah kesalahan penulisan jawaban akhir (encoding error) yaitu sebesar 42,22\%. Menurut Darmawan et al. (2018), kesalahan penulisan jawaban akhir (encoding error) adalah kesalahan yang dilakukan siswa dalam menuliskan jawaban akhir dapat berupa kesalahan dalam penyesuaian konteks atau kesalahan penulisan kata dan kalimat. Pada penelitian ini, kesalahan penulisan jawaban yang dilakukan siswa adalah tidak menuliskan kesimpulan, menuliskan kesimpulan tetapi tidak tepat, serta menuliskan kesimpulan tetapi salah. Adapun kesalahan yang paling sedikit dilakukan oleh siswa adalah kesalahan transformasi (transformation error) yaitu sebesar 5,56\%, diikuti jenis kesalahan lainnya yaitu kesalahan membaca (reading error) sebesar 17,78\%, kesalahan memahami soal (comprehension error) sebesar $30 \%$, serta kesalahan keterampilan proses (process skill error) sebesar 23,33\%. Masing-masing kesalahan yang dilakukan siswa berdasarkan prosedur Newman tersebut, akan dibahas lebih rinci sebagai berikut.

\section{Kesalahan Membaca (Reading Error)}

Kesalahan membaca dialami oleh 16 siswa yang mengerjakan tiga soal cerita, dalam hal ini rata-rata persentasenya sebesar $17,78 \%$. Angka yang tidak terlalu besar, yang artinya sebagian siswa tidak mengalami kesalahan dalam membaca soal. Menurut Rindyana (2013) kesalahan membaca soal (reading errors) terjadi ketika siswa tidak dapat memaknai kalimat yang mereka baca secara tepat. Dalam penelitian ini, siswa yang mengalami kesalahan membaca rata-rata mengalami kesalahan dalam memaknai kalimat dengan tepat, kesalahan dalam menemukan kata kunci atau informasi dalam soal, serta kesalahan dalam memodelkan bahasa matematika ke dalam simbol matematika. Contoh kesalahan membaca adalah kesalahan yang dilakukan oleh siswa 19 (S-19) pada saat mengerjakan soal nomor 2. Contoh kesalahan tersebut dapat dilihat pada Gambar 1.

\begin{abstract}
Soal nomor 2:
Toko "SUBUR" menyediakan 2 merek pupuk, yaitu standar dan super. Setiap jenis mengandung campuran bahan nitrogen dan fosfat dalam jumlah tertentu. Pupuk standar mengandung $2 \mathrm{~kg}$ nitrogen tiap sak dan fosfat mengandung $4 \mathrm{~kg}$ tiap sak. Pupuk super mengandung nitrogen $4 \mathrm{~kg}$ tiap sak dan fosfat $3 \mathrm{~kg}$ tiap sak. Petani tersebut membutuhkan paling sedikit 16 $\mathrm{kg}$ nitrogen dan $24 \mathrm{~kg}$ fosfat untuk pertaniannya. Harga pupuk standar dan super masing-masing Rp30.000,00 dan Rp60.000,00. Berapa banyak masing-masing jenis pupuk yang harus dibeli agar total harga pupuk mencapai minimum dan kebutuhan pupuk untuk lahannya terpenuhi?
\end{abstract}

\section{Gambar 1. Contoh kesalahan membaca}

Pada Gambar 1 terlihat bahwa S-19 melakukan kesalahan membaca yaitu tidak membaca informasi dalam soal dengan teliti. Pada soal yang diberikan, diketahui bahwa "Petani tersebut membutuhkan paling sedikit 16 kg nitrogen dan 24 kg fosfat untuk pertaniannyd". Namun karena S-19 tidak membaca secara teliti sehingga ia melakukan kesalahan dalam memodelkan bahasa matematika tersebut ke dalam simbol matematika yaitu simbol " $\leq$ " yang seharusnya " $\geq$ ".

\section{Kesalahan Memahami Soal (Comprehension Error)}

Kesalahan memahami masalah dialami oleh 27 siswa yang mengerjakan soal, dalam hal ini rata-rata persentasenya sebesar 30\%. Hal ini menunjukkan bahwa kesalahan memahami masalah tergolong tinggi. Menurut Singh et al. (2010) kesalahan memahami masalah (comprehension error) terjadi ketika siswa mampu membaca soal namun gagal memahami apa yang dimaksudkan/diperlukan dari soal, sehingga siswa tersebut gagal dalam menyelesaikan masalah. Dalam penelitian ini siswa yang mengalami kesalahan memahami soal rata-rata tidak 
menuliskan apa yang diketahui dan ditanyakan, menuliskan apa yang diketahui dan ditanyakan tetapi tidak tepat. Contoh kesalahan memahami masalah adalah kesalahan yang dilakukan oleh siswa 7 (S-7) pada saat mengerjakan soal nomor 2. Contoh kesalahan tersebut dapat dilihat pada Gambar 2.

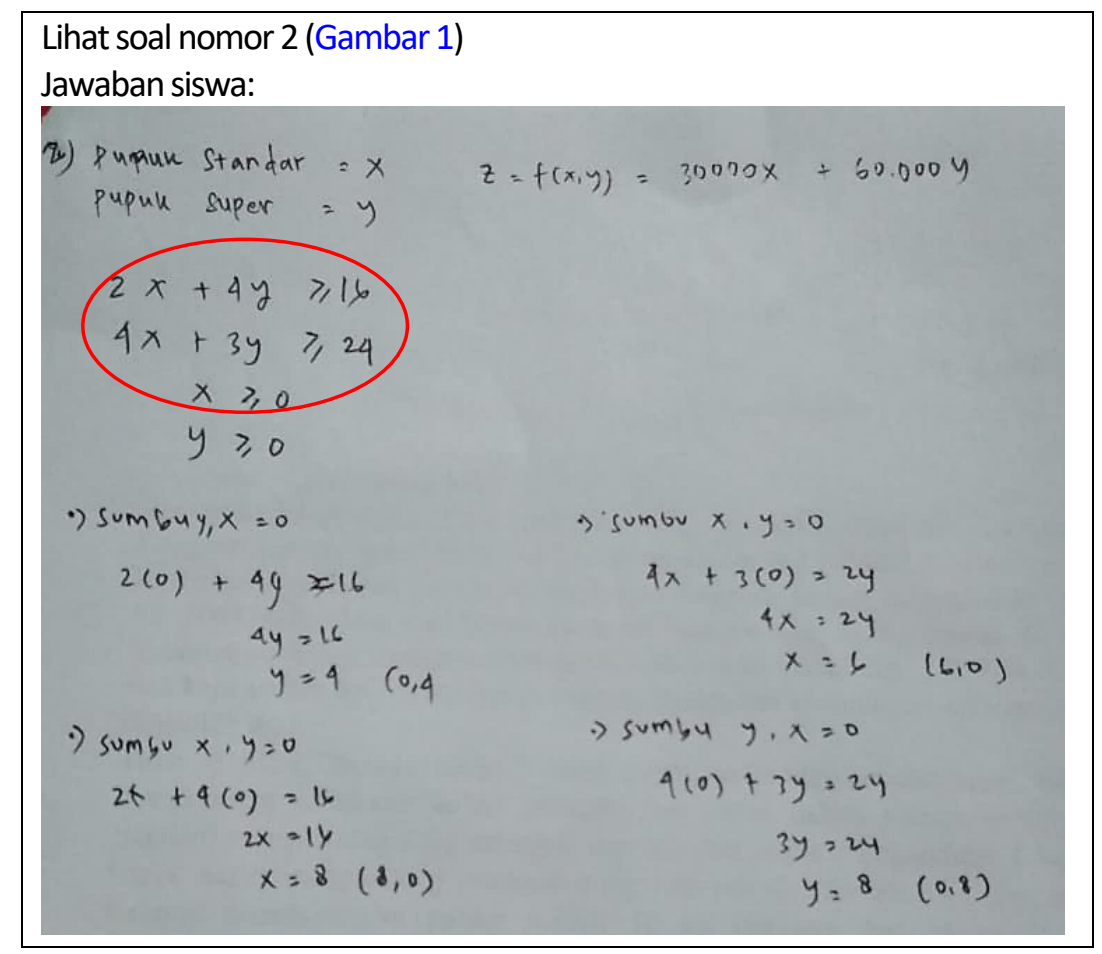

Gambar 2. Contoh kesalahan memahami masalah

Pada Gambar 2 terlihat bahwa S-7 tidak menuliskan apa yang diketahui dan ditanyakan. Pada umumnya siswa melakukan kesalahan dengan menuliskan apa yang diketahui tetapi tidak tepat. Namun S-7 sama sekali tidak menuliskan apa yang diketahui dan yang ditanyakan, $\mathrm{S}-7$ hanya memisalkan pupuk standar $=x$ dan pupuk super $=$ $y$ dan langsung memodelkan masalah ke dalam simbol matematika (lingkaran merah Gambar 2).

\section{Kesalahan Transformasi (Transformation Error)}

Kesalahan transformasi dialami oleh lima siswa yang mengerjakan soal cerita, dalam hal ini rata-rata persentasenya sebesar 5,56\%. Hal ini menunjukkan bahwa kesalahan transformasi tergolong rendah. Menurut Mahmudah \& Sutarni (2017) kesalahan transformasi terjadi karena siswa salah dalam melakukan transformasi dari kata-kata yang ada dalam soal menjadi model matematika untuk diselesaikan. Dalam penelitian ini kesalahan transformasi yang dilakukan siswa adalah kesalahan dalam mentransformasikan informasi yang mereka ketahui dalam soal ke dalam model matematika yang benar, tidak memahami langkah-langkah yang harus dilakukan untuk menyelesaikan soal, serta tidak teliti ketika menyelesaikan soal dan salah melakukan operasi dalam mengerjakan soal. Contoh kesalahan transformasi adalah kesalahan yang dilakukan oleh siswa 11 (S-11) pada saat mengerjakan soal nomor 2. Contoh kesalahan tersebut dapat dilihat pada Gambar 3. Pada Gambar 3 terlihat bahwa S-11 melakukan kesalahan transformasi yaitu tidak mampu mentransformasikan masalah ke dalam model matematika dan tidak teliti dalam melakukan operasi ketika mengerjakan soal. Dalam gambar tersebut S-11 salah dalam membuat model matematika $2 x+4 y \leq 16$ dan $4 x+3 y \leq 24$ yang seharusnya menjadi $2 x+4 y \geq 16$ dan $4 x+3 y \geq 24$ (lingkaran merah Gambar 3). S-11 juga salah menuliskan fungsi tujuan untuk memperoleh harga minimum (garis bawah merah Gambar 3) serta tidak teliti dalam melakukan operasi dalam menyelesaikan soal (kotak merah Gambar 3). 


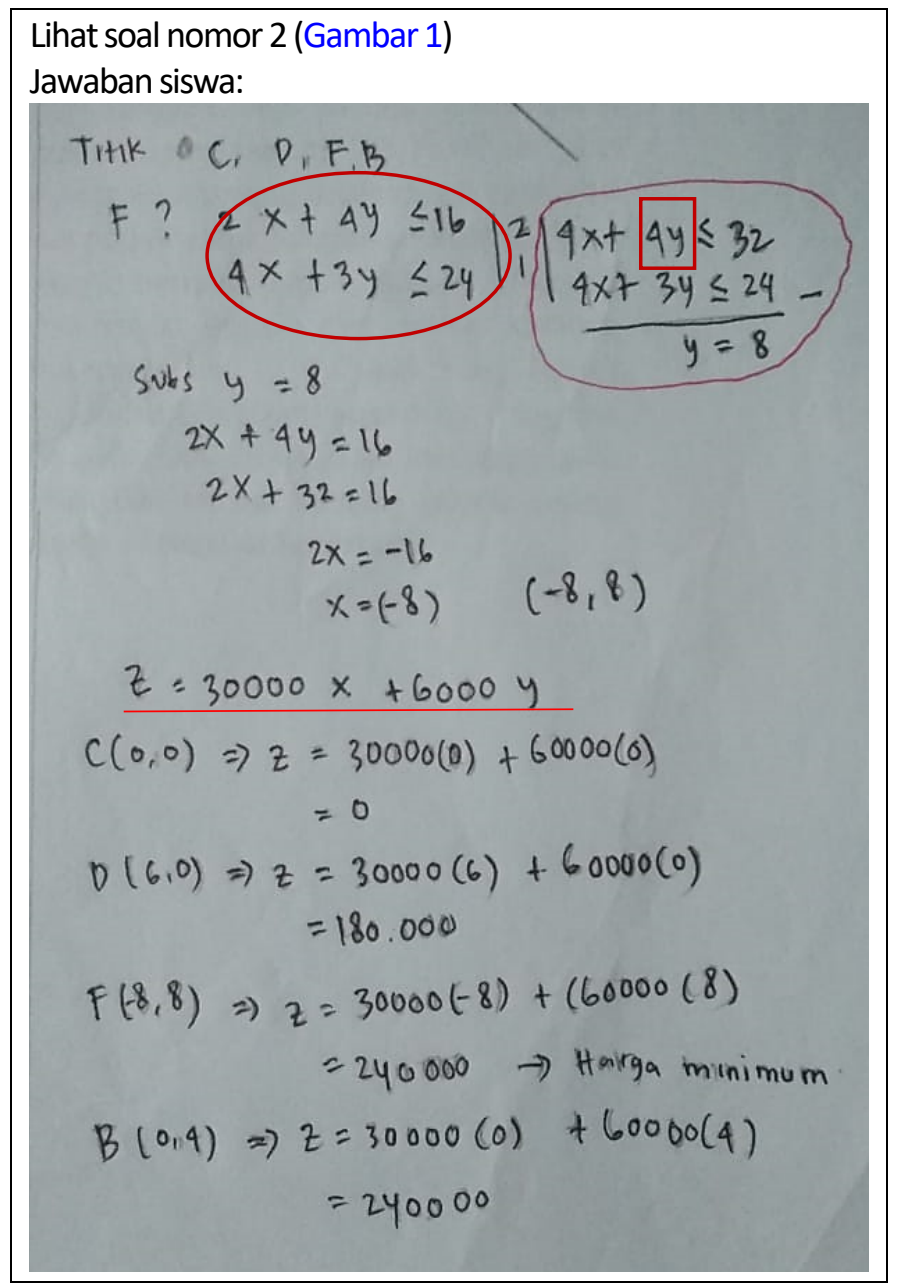

Gambar 3. Contoh kesalahan transformasi

\section{Kesalahan Keterampilan Proses (Process Skills Error)}

Kesalahan keterampilan proses dialami oleh 21 siswa yang mengerjakan soal cerita, dalam hal ini rata-rata persentasenya sebesar 23,33\%. Hal ini menunjukkan bahwa kesalahan keterampilan proses tergolong cukup tinggi. Menurut Sangadah (2016) process skills errors meliputi ommited data dan skills hierarchy problem dengan variasi kesalahan yang dilakukan siswa yaitu, salah dalam melakukan operasi hitung, tidak melakukan operasi untuk mencari solusi atau tidak selesai dalam mengerjakan. Pada penelitian ini siswa mengalami kesalahan keterampilan proses yaitu melakukan kesalahan dalam menggunakan kaidah atau aturan matematika yang benar, tidak dapat memproses lebih lanjut solusi dari penyelesaian soal, dan mengalami kesalahan dalam melakukan perhitungan. Contoh kesalahan keterampilan proses adalah kesalahan yang dilakukan oleh siswa 6 (S-6) dan siswa 25 (S-25) pada saat mengerjakan soal nomor 2 dan 3 . Contoh kesalahan tersebut dapat dilihat pada Gambar 4 (a) dan Gambar 4 (b).

Pada Gambar 4 (a) terlihat bahwa S-6 tidak dapat memproses lebih lanjut solusi dari penyelesaian soal, sehingga belum menemukan jawaban akhir. Sedangkan pada Gambar 4 (b) terlihat bahwa S-25 salah dalam menuliskan fungsi tujuan yang akan dicapai yaitu $f(x, y)=1000 x+1500 y$ (kotak warna merah) karena S-25 memisalkan $x=$ pupuk kering dan $y=$ pupuk cair, seharusnya fungsi tujuan yang benar adalah $f(x, y)=$ $1000 y+1500 x$. S-25 sebenarnya mampu menentukan koordinat titik sudut daerah layak dari soal program linear dan menggambar daerah layak. Namun, siswa tidak mengetahui langkah-langkah yang akan digunakan untuk menyelesaikan masalah dengan tepat, sehingga siswa berhenti di tengah jalan dan tidak mampu menyelesaikan permasalahan pada soal cerita tersebut. 


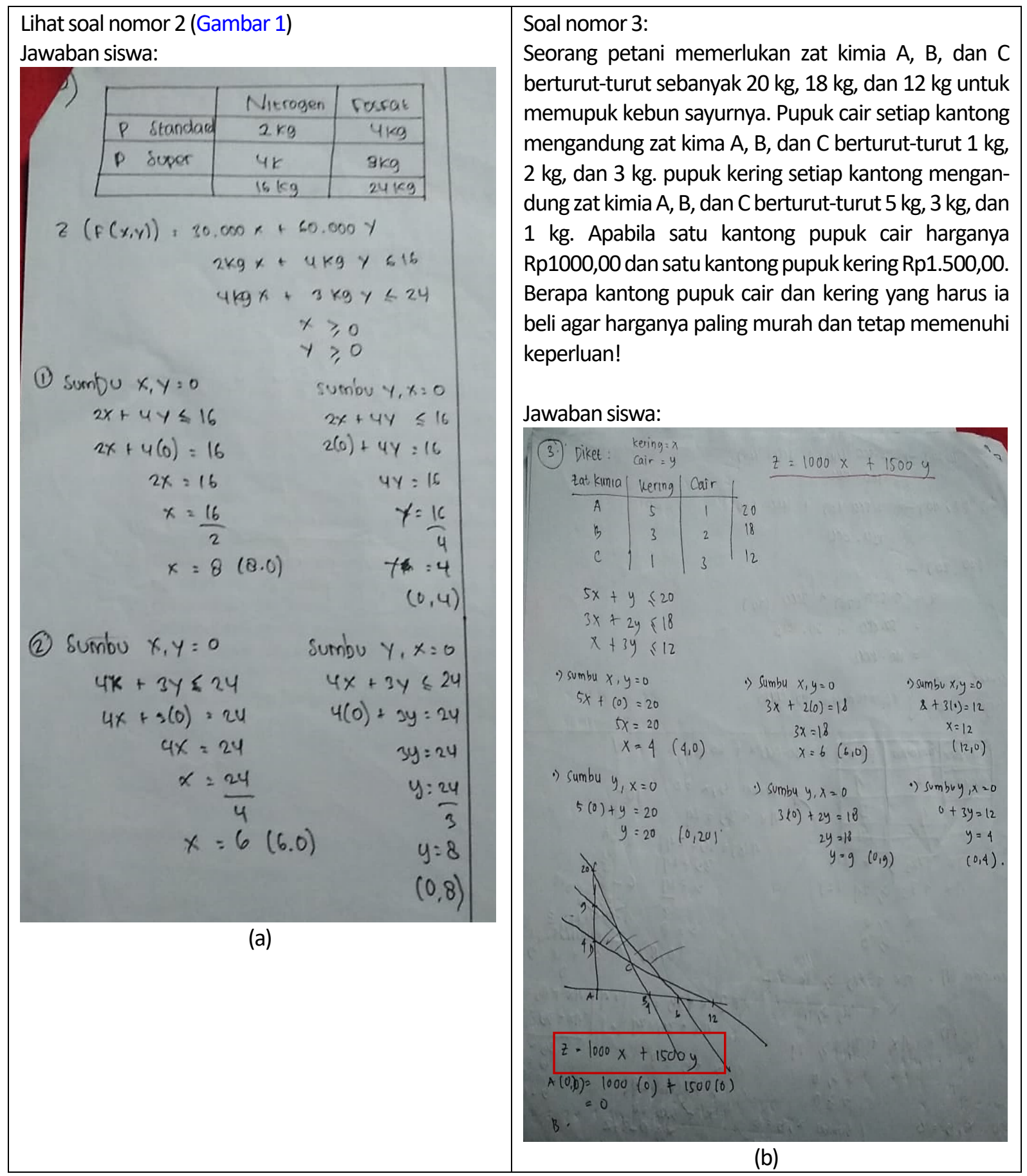

Gambar 4. Contoh kesalahan keterampilan proses: (a) siswa tidak dapat melanjutkan proses penyelesaian soal;

(b) siswa salah menuliskan fungsi tujuan

\section{Kesalahan Penulisan Jawaban Akhir (Encoding Error)}

Kesalahan penulisan jawaban akhir dialami oleh 38 siswa yang mengerjakan soal cerita, dalam hal ini rata-rata persentasenya sebesar 42,22\%. Hal ini menunjukkan bahwa kesalahan penulisan jawaban akhir merupakan kesalahan yang paling tinggi di antara kesalahan lainnya. Menurut Singh et al. (2010) kesalahan penentuan jawaban akhir (encoding errors) terjadi walaupun siswa telah mampu mengerjakan dengan benar masalah matematika, namun dengan kecerobohannya siswa tersebut menulis jawaban akhir yang salah. Dalam penelitian ini siswa mengalami kesalahan penulisan jawaban akhir berupa siswa melakukan kesalahan dalam menuliskan satuan dari jawaban akhir, tidak menuliskan kesimpulan, dan menuliskan kesimpulan tetapi tidak tepat. Contoh kesalahan 
keterampilan proses adalah kesalahan yang dilakukan oleh siswa 3 (S-3) dan siswa 17 (S-17) pada saat mengerjakan soal nomor 1. Contoh kesalahan tersebut dapat dilihat pada Gambar 5 (a) dan Gambar 5 (b).

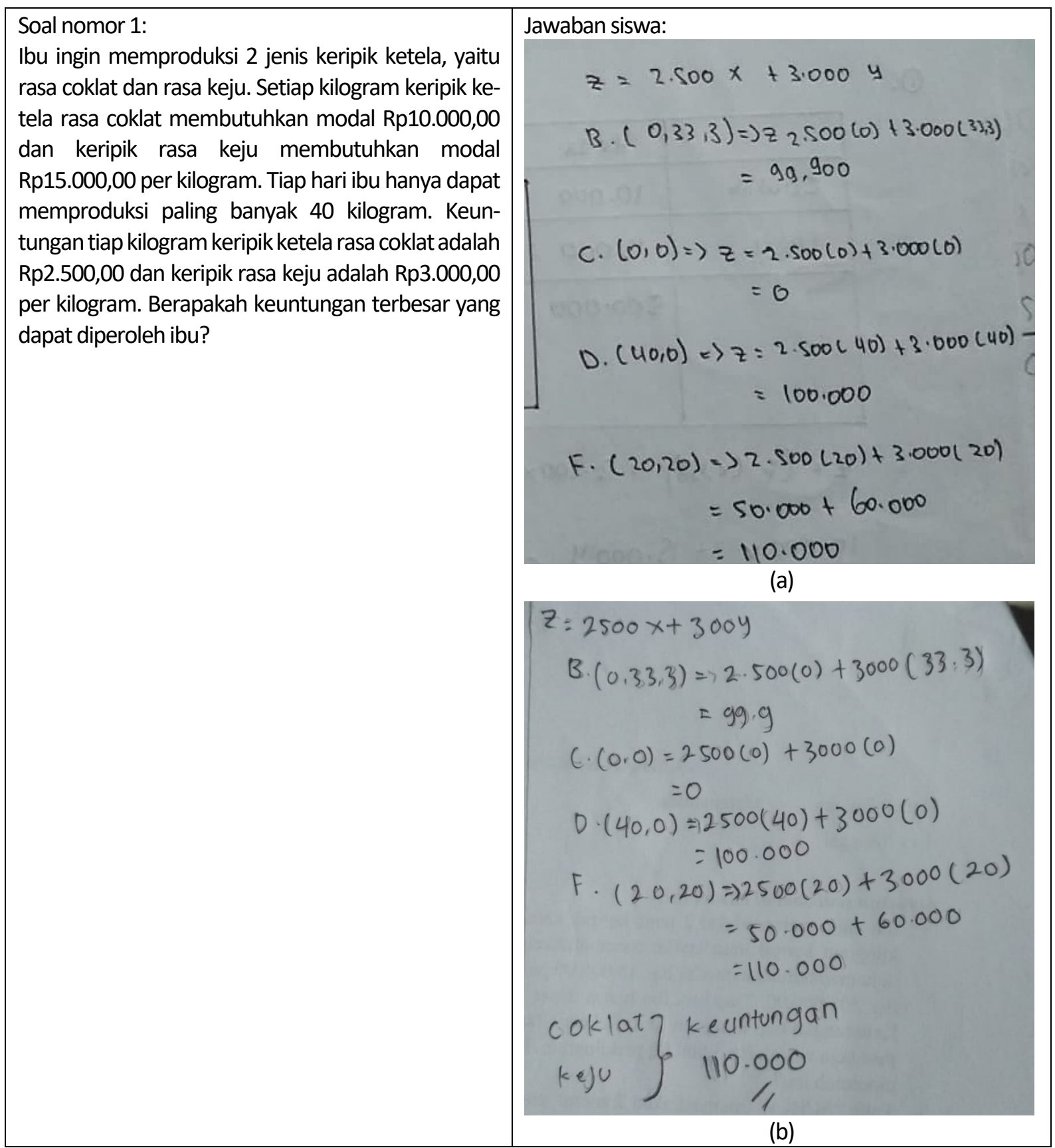

Gambar 5. Contoh kesalahan penulisan jawaban akhir: (a) siswa tidak menuliskan kesimpulan; (b) siswa menuliskan kesimpulan tetapi kurang tepat

Pada Gambar 5 (a) terlihat bahwa S-3 tidak menuliskan kesimpulan, sedangkan pada Gambar 5 (b) terlihat bahwa S-17 menuliskan kesimpulan tetapi kurang tepat. Sebenarnya S-3 dan S-17 mampu menemukan hasil akhir dari soal dengan benar yaitu keuntungan maksimum yang diperoleh pedagang kue sebesar $\mathrm{Rp} 110.000,00$, namun siswa belum mampu menunjukkan jawaban akhir dengan benar dan tidak dapat menuliskan kesimpulan jawaban akhir dengan tepat dan akurat. Kesimpulan dari penyelesaian soal tersebut adalah seperti berikut: ibu akan mendapatkan keuntungan sebesar Rp110.000,00 ketika menjual 20 ketela rasa coklat dan 20 ketela rasa keju.

\section{PEMBAHASAN}

Berdasarkan hasil penelitian yang telah dikemukakan, berikut adalah pembahasan secara rinci dari setiap kesalahan yang dilakukan siswa dalam menyelesaikan soal cerita pada materi program linear. 


\section{Kesalahan Membaca (Reading Error)}

Berdasarkan hasil analisis jawaban siswa, dapat disimpulkan bahwa kesalahan membaca yang dilakukan siswa berupa kesalahan memaknai kalimat dengan tepat, kesalahan dalam menemukan kata kunci atau informasi dalam soal, serta kesalahan dalam memodelkan bahasa matematika ke dalam simbol matematika. Hal ini sesuai dengan penelitian yang dilakukan oleh Singh et al. (2010) bahwa kesalahan membaca terjadi ketika kata-kata atau simbol yang tertulis gagal diakui oleh subjek yang menyebabkannya gagal untuk menyelesaikan masalah berdasarkan langkah-langkah penyelesaian yang tepat. Hal tersebut juga sejalan dengan sebuah studi yang menunjukkan bahwa semakin baik teknik membaca seseorang, semakin baik pula kemampuan penyelesaian soal matematikanya (Vilenius-Tuohimaa et al., 2008).

\section{Kesalahan Memahami Soal (Comprehension Error)}

Berdasarkan hasil analisis jawaban siswa, dapat disimpulkan bahwa kesalahan membaca yang dilakukan siswa berupa tidak menuliskan apa yang diketahui dan apa yang ditanyakan dalam soal. Kesalahan memahami masalah dapat terjadi karena siswa belum mampu memahami kata-kata kunci yang ada pada soal, siswa tidak mengetahui informasi penting pada soal dan apa yang ditanyakan dalam soal. Hal ini sesuai dengan penelitian yang dilakukan oleh Chusnul et al. (2017) yang melaporkan bahwa siswa melakukan kesalahan pemahaman dengan tidak menuliskan informasi dan pertanyaan dari soal.

\section{Kesalahan Transformasi (Transformation Error)}

Berdasarkan hasil analisis jawaban siswa, dapat disimpulkan bahwa kesalahan transformasi yang dilakukan siswa berupa tidak mampu mentransformasikan masalah ke dalam model matematika dan tidak teliti dalam melakukan operasi matematika ketika mengerjakan soal. Kesalahan transformasi dapat terjadi karena siswa memahami apa yang ditanyakan, tetapi tidak berhasil dalam mengembangkan operasi matematika yang sesuai untuk menyelesaikan masalah. Salah satu kesalahan yang dilakukan siswa dalam menyelesaikan soal cerita adalah mentransformasikan informasi yang relevan ke dalam persamaan matematika (Brown \& Skow, 2016).

\section{Kesalahan Keterampilan Proses (Process Skills Error)}

Berdasarkan hasil analisis tes pada siswa dapat disimpulkan bahwa kesalahan keterampilan proses yang dilakukan siswa berupa tidak mengetahui langkah-langkah yang akan digunakan untuk menyelesaikan masalah dengan tepat, dan mengalami kesalahan prosedur seperti salah dalam menulis fungsi tujuan yang akan dicapai. Hal ini sejalan dengan pendapat Jha (2012) bahwa kesalahan keterampilan proses yaitu siswa mampu mengidentifikasi operasi yang sesuai, atau serangkaian operasi, tetapi tidak tahu langkah-langkah yang diperlukan untuk melaksanakan operasi ini dengan sempurna. Hal ini juga sesuai dengan penelitian Tambychik dan Meerah (2010), bahwa siswa mengalami kesulitan dalam proses pemecahan masalah matematika karena ketidakcakapan dalam menguasai keterampilan matematika.

\section{Kesalahan Penulisan Jawaban Akhir (Encoding Error)}

Berdasarkan hasil analisis jawaban siswa, dapat disimpulkan bahwa kesalahan penulisan jawaban akhir yang dilakukan siswa berupa tidak mampu menemukan hasil akhir dari soal dengan benar, tidak mampu menunjukkan jawaban akhir dengan benar, dan tidak dapat menuliskan kesimpulan sesuai dengan yang diharapkan. Kesalahan penulisan jawaban akhir (encoding error) sangat disayangkan, karena siswa telah berhasil mencapai tahap pengolahan data, tetapi gagal atau belum menuliskan solusi akhir. Kesalahan ini dapat terjadi karena kesalahan dalam proses penyelesaian soal pada tahap sebelumnya dan atau siswa kurang memahami tentang isu-isu penting yang terdapat pada soal (Santoso et al., 2017).

\section{Implikasi}

Dengan mengetahui kesalahan-kesalahan yang dilakukan oleh siswa dalam menyelesaikan soal cerita program linear berdasarkan prosedur Newman, guru dapat menggunakannya sebagai acuan dalam menentukan rancangan pembelajaran yang sesuai untuk meminimalisir terjadinya kesalahan yang serupa. Berdasarkan temuan penelitian ini, disarankan kepada guru untuk memperkuat pemahaman konsep siswa terhadap materi yang dipelajari. Ketika siswa dihadapkan dengan permasalahan kontekstual yang biasanya disajikan dalam bentuk soal cerita, siswa akan gagal dan merasa kesulitan jika tidak memiliki pemahaman konsep yang baik. Untuk itu guru hendaknya 
lebih banyak memberikan latihan soal-soal cerita yang bervariasi dari soal yang sederhana hingga soal yang lebih kompleks agar siswa terbiasa. Guru juga perlu melakukan perbaikan dalam proses pembelajaran, juga memanfaatkan berbagai media dan teknologi dalam proses belajar mengajar sebagai upaya agar proses pembelajaran semakin lebih baik.

\section{SIMPULAN}

Berdasarkan hasil penelitian dan pembahasan, dapat disimpulkan bahwa dalam menyelesaikan soal cerita program linear masih banyak siswa yang melakukan kesalahan. Kesalahan membaca ditandai dengan kesalahan memaknai kalimat dengan tepat, kesalahan dalam menemukan kata kunci atau informasi dalam soal, serta kesalahan dalam memodelkan bahasa matematika ke dalam simbol matematika. Kesalahan memahami masalah ditandai dengan tidak menuliskan apa yang diketahui dan ditanyakan atau menuliskan apa yang diketahui dan ditanya tetapi tidak tepat. Kesalahan transformasi ditandai dengan tidak menggunakan operasi matematika yang tepat dalam menyelesaikan soal. Kesalahan keterampilan proses ditandai dengan kesalahan dalam menggunakan aturan matematika, kesalahan dalam perhitungan, dan proses perhitungan yang tidak selesai. Kesalahan menarik kesimpulan ditandai dengan kesalahan menuliskan satuan, tidak menuliskan kesimpulan, dan menuliskan kesimpulan tetapi tidak tepat. Dari kesalahan-kesalahan yang dilakukan oleh siswa, kesalahan penulisan jawaban akhir merupakan kesalahan yang paling banyak dilakukan oleh siswa. Untuk itu siswa perlu dibiasakan untuk menyelesaikan soal cerita secara sistematis dan sampai pada tahap kesimpulan, yaitu mengaitkan jawaban akhir dengan apa yang ditanyakan pada soal. Mengingat masih banyaknya keterbatasan dalam penelitian ini, untuk itu diharapkan agar peneliti lain dapat melakukan penelitian serupa dengan melibatkan subjek penelitian yang lebih beragam serta memilih materi-materi matematika lainnya.

\section{DAFTAR PUSTAKA}

Angateeah, K. S. (2017). An investigation of students' difficulties in solving non-routine word problem at lower secondary. International Journal of Learning and Teaching, 3(1), 46-50. https://doi.org/https://doi.org/10.18178/ijtt.3.1.46-50

Boonen, A. J. H., de Koning, B. B., Jolles, J., \& van der Schoot, M. (2016). Word problem solving in contemporary math education: A plea for reading comprehension skills training. Frontiers in Psychology, 7(1), 1-10. https://doi.org/https://doi.org/10.3389/fpsyg.2016.00191

Brown, J., \& Skow, K. (2016). Mathematics identifying and addressing student errors. The IRIS Center.

Budiyono, B. (2008). Kesalahan mengerjakan soal cerita dalam pembelajaran matematika. Paedagogia: Jurnal Penelitian Pendidikan, 11(1), 1-8. https://doi.org/10.20961/paedagogia.v11i1.35977

Chusnul, C., Mardiyana, M., \& Retno, D. S. (2017). Errors analysis of problem solving using the Newman stage after applying cooperative learning of TTW type. AIP Conference Proceedings, 1913(1), 020028. https://doi.org/10.1063/1.5016662

Darmawan, I., Kharismawati, A., Hendriana, H., \& Purwasih, R. (2018). Analisis kesalahan siswa SMP berdasarkan Newman dalam menyelesaikan soal kemampuan berpikir kritis matematis pada materi bangun ruang sisi datar. Juring: Journal for Research in Mathematics Learning, 1(1), 71-78. http://dx.doi.org/10.24014/juring.v1i1.4912

Fitriatien, S. R. (2019). Analisis kesalahan dalam menyelesaikan soal cerita matematika berdasarkan Newman. JIPMat: Jurnal IImiah Pendidikan Matematika, 4(1). 53-64. https://doi.org/10.26877/jipmat.v4i1.3550

Hadi, S., Retnawati, H., Munadi, S., Apino, E., \& Wulandari, N. F. (2018). The difficulties of high school students in solving higher-order thinking skills problems. Problems of Education in the 21st Century, 76(4), 520-532. https://dx.doi.org/10.33225/pec/18.76.520

Haryarti, T., Suyitno, A., \& Junaedi, I. (2016). Analisis kesalahan siswa SMP kelas VII dalam menyelesaikan soal cerita pemecahan masalah berdasarkan prosedur Newman. Unnes Journal of Mathematics Education, 5(1), 9-15. https://doi.org/10.15294/ujme.v5i1.9341

Jamal, F. (2018). Analisis kesalahan dalam menyelesaikan soal cerita pertidaksamaan kuadrat berdasarkan prosedur Newman. Maju: Jurnal Ilmiah Pendidikan Matematika, 5(2), 41-51.

https://ejournal.stkipbbm.ac.id/index.php/mtk/article/view/198 
Jha, S. K. (2012). Mathematics performance of primary school students in Assam (India): An analysis using Newman procedure. International Journal of Computer Applications in in Engineering Sciences, II(I), 17-21.

Larasati, S. R. (2018). Analisis kemampuan memodelkan siswa kelas XI SMA Pangudi Luhur Yogyakarta pada pembelajaran matematika materi program linear dengan menggunakan pendekatan pembelajaran matematika realistik (PMR) [Undergraduate thesis, Universitas Sanata Dharma]. https://repository.usd.ac.id/34265/

Mahmudah, I. D., \& Sutarni, S. (2017). Kesalahan siswa dalam menyelesaikan soal program linier bentuk cerita berbasis Newman di MAN Salatiga. Prosiding SEMPOA 3 (Seminar Nasional, Pameran Alat Peraga, dan Olimpiade Matematika), Universitas Muhammadiyah Surakarta (pp. 1-8). http://hdl.handle.net/11617/8775

Newman, A. (1983). Newman language of mathematics kit: Strategies for diagnosis and remediation. Pearson Education Australia.

Nurussafa'at, F. A., Sujadi, I., \& Riyadi, R. (2016). Analisis kesalahan siswa dalam menyelesaikan soal cerita pada materi volume prisma dengan Fong's schematic model for error analysis ditinjau dari gaya kognitif siswa. Jurnal Elektronik Pembelajaran Matematika, 4(2), 174-187. https://jurnal.uns.ac.id/jpm/article/view/10862

Pradini, W. (2019). Analisis kesalahan siswa dalam menyelesaikan soal cerita persamaan linear dua variabel. Pyhtagoras: Jurnal Pendidikan Matematika, 14(1), 33-45. https://doi.org/10.21831/pg.v14i1.21481

Puspendik. (n. d.). Laporan hasil ujian nasional. https://hasilun.puspendik.kemdikbud.go.id/

Rafi, I., \& Retnawati, H. (2018). What are the common errors made by students in solving logarithm problems? Journal of Physics: Conference Series, 1097, 012157. https://doi.org/10.1088/1742-6596/1097/1/012157

Rahardjo, M., \& Waluyati, A. (2011). Modul matematika SD program BERMUTU: Pembelajaran soal cerita operasi hitung campuran di sekolah dasar. Pusat Pengembangan dan Pemberdayaan Pendidik dan Tenaga Kependidikan Matematika.

Rahmawati, D., \& Permata, L. D. (2018). Analisis kesalahan siswa dalam menyelesaikan soal cerita program linear dengan prosedur Newman. Jurnal Elektronik Pembelajaran Matematika, 5(2), 173-185. https://jurnal.uns.ac.id/jpm/article/view/26050

Rindyana, B. S. B. (2013). Analisis kesalahan siswa dalam menyelesaikan soal cerita matematika materi sistem persamaan linear dua variabel berdasarkan analisis Newman (studi kasus MAN Malang 2 Batu) [Undergradute thesis, Universitas Negeri Malang]. http://repository.um.ac.id/15794/

Sangadah, M. (2016). Analisis kesalahan siswa SMP menyelesaikan soal matematika pokok bahasan sistem persamaan linear dua variabel. Ekuivalen, 20(1), 12-18. https://doi.org/10.37729/ekuivalen.v20i1.2865

Santoso, D. A., Farid, A., \& Ulum, B. (2017). Error analysis of students working about word problem of linear program with NEA procedure. Journal of Physics: Conference Series, 855(1), 012043. https://doi.org/10.1088/1742$6596 / 855 / 1 / 012043$

Satoto, S. (2012). Analisis kesalahan hasil belajar siswa kelas XSMA Negeri 1 Kendal dalam menyelesaikan soal materijarak pada bangun ruang [Undergraduate thesis, Universitas Negeri Semarang]. http://lib.unnes.ac.id/id/eprint/18693

Satoto, S., Sutarto, H., \& Pujiastuti, E. (2013). Analisis kesalahan hasil belajar siswa dalam menyelesaikan soal dengan prosedur Newman. Unnes Journal of Mathematics Education, 1(2), 1-7. https://doi.org/10.15294/ujme.v1i2.1757

Seifi, M., Haghverdi, M., \& Azizmohamadi, F. (2012). Recognition of students' difficulties in solving mathematical word problems from the viewpoint of teachers contextual and conceptual rewording view project. Journal of Basic and Applied Scientific Research, 2(3), 2923-2928.

Singh, P., Rahman, A. A., \& Hoon, T. S. (2010). The Newman procedure for analyzing primary four pupils errors on written mathematical tasks: A Malaysian perspective. Procedia - Social and Behavioral Sciences, 8(5), 264271. https://doi.org/10.1016/j.sbspro.2010.12.036

Soedjadi, S. (2000). Kiat pendidikan matematika di Indonesia. Direktorat Jendral Pendidikan Tinggi Departemen Pendidikan Nasional. 
Tambychik, T., \& Meerah, T. S. M. (2010). Students' difficulties in mathematics problem-solving: What do they say? Procedia - Social and Behavioral Sciences, 8, 142-151. https://doi.org/10.1016/j.sbspro.2010.12.020

Vilenius-Tuohimaa, P. M., Aunola, K., \& Nurmi, J. -E. (2008). The association between mathematical word problems and reading comprehension. Educational Psychology, 28(4), 409-426. https://doi.org/10.1080/01443410701708228

White, A. L. (2010). Numeracy, literacy and Newman's error analysis. Journal of Science and Mathematics Education in Southeast Asia, 33(2), 129-148. 